Tropical Journal of Pharmaceutical Research January 2016; 15 (1): 107-113

ISSN: 1596-5996 (print); 1596-9827 (electronic)

(c) Pharmacotherapy Group, Faculty of Pharmacy, University of Benin, Benin City, 300001 Nigeria.

All rights reserved.

Available online at http://www.tjpr.org

Original Research Article

http://dx.doi.org/10.4314/tjpr.v15i1.15

\title{
Chemical Composition and Antimicrobial Activity of Geniosporum rotundifolium Briq and Haumaniastrum villosum (Bene) AJ Paton (Lamiaceae) Essential Oils from Tanzania
}

\author{
Olipa D Ngassapa ${ }^{1 \star}$, Deborah KB Runyoro', Konstantinos Vagionas², \\ Konstantia Graikou ${ }^{2}$ and loanna B Chinou ${ }^{2}$ \\ ${ }^{1}$ Department of Pharmacognosy, School of Pharmacy, Muhimbili University of Health and Allied Sciences (MUHAS), PO Box \\ 65013, Dar es Salaam, Tanzania, 'Division of Pharmacognosy \& Chemistry of Natural Products, School of Pharmacy, \\ University of Athens, University Campus of Zografou, 15771 Athens, Greece
}

*For correspondence: Email: ongassapa@muhas.ac.tz; o_ngassapa@yahoo.co.uk; Tel: +255-713-246 227; Fax: +255-222150465

\begin{abstract}
Purpose: To determine the chemical composition and antimicrobial potential of essential oils from two aromatic plants of Tanzania, Geniosporum rotundifolium Briq. and Haumaniastrum villosum (Benè) A.J. Paton (Lamiaceae).

Method: Essential oils from the aerial parts of the plants were extracted by hydro-distillation for $3 \mathrm{~h}$ using a Clevenger type of apparatus. The constituents were analyzed by gas chromatography - mass spectrometry (GC/MS). The minimum inhibitory concentrations of the essential oils were determined for eight bacterial strains and three pathogenic fungi using agar dilution method.

Results: The constituents of G. rotundifolium oil were mainly oxygenated derivatives of mono- and sesquiterpenes; spathulenol (12.46 \%), $\alpha$-terpineol (4.65\%) and germacrene-D (3.71 \%) were the most abundant. Those of $H$. villosum oil were predominantly sesquiterpenes $(72.61 \%)$ with caryophyllene oxide (19.01\%), humulene epoxide II (11.95\%), $\beta$-bourbonene (5.7\%), $\alpha$-humulene (5.63\%) and $\beta$ caryophyllene (5.39\%) being more abundant. The oil of G. rotundifolium exhibited weak to moderate activity against the bacterial species but showed no activity against the test fungi. However, $\mathrm{H}$. villosum oil showed very promising activity against all the test microorganisms (MIC $0.08-10.34 \mathrm{mg} / \mathrm{mL}$ ).

Conclusion: The major components of G. rotundifolium essential oil were oxygenated derivatives of mono- and sesquiterpenes whereas those of $\mathrm{H}$. villosum were sesquiterpenes. All tested microorganisms were susceptible to $\mathrm{H}$. villosum oil.
\end{abstract}

Keywords: Geniosporum rotundifolium, Haumaniastrum villosum, Essential oils, Chemical composition, Antimicrobial activity

Tropical Journal of Pharmaceutical Research is indexed by Science Citation Index (SciSearch), Scopus, International Pharmaceutical Abstract, Chemical Abstracts, Embase, Index Copernicus, EBSCO, African Index Medicus, JournalSeek, Journal Citation Reports/Science Edition, Directory of Open Access Journals (DOAJ), African Journal Online, Bioline International, Open-J-Gate and Pharmacy Abstracts

\section{INTRODUCTION}

Geniosporum rotundifolium Briq. and Haumaniastrum villosum (Benè) A.J. Paton (Lamiaceae) are known as "Nkulilo" in the
Nyakyusa dialect of Rungwe District, Mbeya Region, Southwestern Tanzania. Geniosporum rotundifolium (syn. G. paludosum Bak) [1], is a stout, erect, perennial herb which grows in damp grassland at high altitude [2]. It is confined to 
several African countries including Tanzania [3]. Its leaves, stems and essential oils are given in combination with leaves of other plants for a number of medical uses. In Burundi it is used as an enema, cough remedy, laxative and antiabortion while in Uganda it is used against fungal and bacterial infections [4]. A previous study on G. rotundifolium growing in Cameroon indicated that the essential oil from this plant possessed significant antifungal activities against Fusarium moniliforme and Rhizopus stolonifera. Furthermore, its chemical composition was determined with sesquiterpene hydrocarbons constituting more than $90 \%$ of the oil [5].

Haumaniastrum villosum is an annual or shortlived perennial herb confined to the African continent and Madagascar, in the sub-humid climate [6]. There is scanty information on the medicinal uses and biological activities of $H$. villosum and to our knowledge there is no information on its phytochemical studies. Its synonym $H$. galeopsifolium, has been reported to be used traditionally in Burundi, alone or in combination for a number of health problems including urogenital infections [1]. It has also been reported to be used in controlling crop pests in the Democratic Republic of Congo [7].

In the current study, chemical compositions and antimicrobial activities of the essential oils of Geniosporum rotundifolium and Haumaniastrum villosum from Tanzania are reported for the first time.

\section{EXPERIMENTAL}

\section{Plant material}

Aerial parts (leaves and flowering tops) of $G$. rotundifolium and $H$. villosum were collected from the wild, in Rungwe district, Mbeya region, Tanzania in June, 2000. The plants were authenticated by Mr. H. Selemani of the Department of Botany, University of Dar es Salaam. Voucher specimen Nos. ODN/DBR 001 for $G$. rotundifolium and ODN/DBR 002 for $H$. villosum, respectively, were deposited in the herbarium of the Department of Pharmacognosy, School of Pharmacy, Muhimbili University of Health and Allied Sciences.

\section{Isolation of essential oil}

All materials were air-dried in the shade, prior to hydro-distillation of essential oils for $3 \mathrm{~h}$ in a Clevenger-type apparatus. The essential oils collected over water were separated, dried over anhydrous sodium sulfate and stored at $4-6{ }^{\circ} \mathrm{C}$ until chemical analysis and antimicrobial screening.

\section{Gas chromatography}

Gas chromatography (GC) analysis was carried out on a Perkin-Elmer 8500 gas chromatograph with a flame ionization detector (FID), fitted with a Supelcowax-10 fused silica capillary column (30 m x $0.32 \mathrm{~mm}, 0.25 \mu \mathrm{m}$ film-thickness). The column temperature was programmed from 75 to $200{ }^{\circ} \mathrm{C}$ at a rate of $2.5^{\circ} \mathrm{C} / \mathrm{min}$. The injector and detector temperatures were programmed at 230 ${ }^{\circ} \mathrm{C}$ and $300{ }^{\circ} \mathrm{C}$, respectively. Helium was used as the carrier gas, at a flow rate of $1 \mathrm{~mL} / \mathrm{min}$.

\section{Gas chromatography-mass spectrometry}

Gas chromatography-mass spectrometry (GCMS) analysis was carried out using a Hewlett Packard 5973-6890 GC-MS system operating on El mode (equipped with a HP 5 MS $30 \mathrm{~m} \times 0.25$ $\mathrm{mm} \times 0.25 \mu \mathrm{m}$ film thickness capillary column). Helium $(2 \mathrm{~mL} / \mathrm{min})$ was used as the carrier gas. The temperature of the column was programmed from 60 to $280{ }^{\circ} \mathrm{C}$, at a rate of $3{ }^{\circ} \mathrm{C} / \mathrm{min}$. Split ratio, 1:10.

\section{Identification of components}

The compounds were identified by comparison of their retention indices (RI) [8] retention times (RT) and mass spectra with those of authentic samples, viz, 1,8-cineole, camphor, pulegone, piperitone, bornyl acetate, spathulenol, $\beta$ caryophyllene and $\beta$-caryophyllene oxide (Extrasynthese), borneol, linalool, limonene (Fluka AG), $\alpha$-pinene, $\beta$-pinene (Aldrich) and/or the NIST/NBS, Wiley libraries spectra and the literature [9]. The percentage composition of the essential oil is based on computer calculated peak areas without correction for FID response factor.

\section{Evaluation of antimicrobial activity}

Antimicrobial activity of the essential oils against bacteria and fungi was determined using the agar dilution technique. The microorganisms included four Gram-positive bacteria: Staphylococcus aureus (ATCC 25923), Staphylococcus epidermidis (ATCC 12228); Streptococcus mutans and Streptococcus viridian, with the last two being clinical isolates and oral pathogens; four Gram-negative bacteria: Escherichia coli (ATCC 25922), Enterobacter cloacae (ATCC 13047), Klebsiella pneumoniae (ATCC 13883) and Pseudomonas aeruginosa (ATCC 227853); and three species of Candida, namely, C. albicans (ATCC 10231), C. tropicalis 
(ATCC 13801) and C. glabrata (ATCC 28838). Standard antibiotics (netilmicin and amoxicillin) were used as positive controls.

Technical data have been described previously [10]. Briefly, stock solutions of the tested samples were prepared at $10 \mathrm{mg} / \mathrm{mL}$ in dichloromethane. Serial dilutions of the stock solutions in broth medium $(100 \mu \mathrm{L}$ of MüllerHinton broth or on Sabouraud broth for the fungi) were prepared in a microtiter plate (96 wells). Then $1 \mu \mathrm{L}$ of the microbial suspension (the inoculum, in sterile distilled water) was added to each well. For each strain, the growth conditions and the sterility of the medium were checked and the plates were incubated as referred above. Standard antibiotics, netilmicin and amoxicillin (at concentrations $4-88 \mu \mathrm{g} / \mathrm{ml}$ ), were used as positive controls. For each experiment, the pure solvent, dichloromethane, was also applied as negative control. The experiments were repeated three times and the results were expressed as average values. Minimum inhibitory concentrations (MICs) were determined for all the samples and the standard pure compounds, under the same conditions, for comparison purposes. The MICs were taken as the lowest concentrations preventing visible growth.

\section{RESULTS}

The oils obtained from both plant species were pale yellow liquids with slight aromatic smell. The yield was $0.06 \% \mathrm{v} / \mathrm{w}$ for $G$. rotundifolium and $0.12 \% \mathrm{v} / \mathrm{w}$ for $H$. villossum. A total of 59 components, comprising $91.15 \%$ of the oil got separated in the GC of $G$. rotundifolium, of which 54 constituents were identified (Table 1(a), 1(b) and 1 (c). A $44.89 \%$ of the oil was composed of oxygenated derivatives, while mono and sesquiterpene hydrocarbons constituted $36.67 \%$ of the oil. The major compounds identified were spathulenol (12.46\%), a-terpineol (4.65\%) and germacrene-D (3.71\%). In a previous study on plants growing in Cameroon, it was found that sesquiterpene hydrocarbons constituted $90.1 \%$ of the oil with germacrene $D, \beta$-caryophyllene and $\beta$-gurjunene being the major components [5]. The difference in the composition could be attributed to differences in the geographical location, climate, season and age at which the plants were collected.

In the essential oil of Haumaniastrum villosum, a total of 44 components were identified, representing $85.6 \%$ of the oil (Table 2(a) and 2(b)); oxygenated derivatives were again the most abundant chemical category (44.48\% followed by mono- and sesquiterpene hydrocarbons (34.24\%) The most abundant components were caryophyllene oxide (19.01 $\%)$, humulene epoxide II (11.95\%), $\beta$ bourbonene $(5.7 \%)$, $\alpha$-humulene $(5.63 \%)$ and $\beta$-caryophyllene (5.39\%).

The oils as well as pure reference compounds were tested for antimicrobial activity against eight bacterial species and three species of Candida. The antimicrobial activity as minimum growth inhibitory concentrations of the essential oils, some pure components and the reference antimicrobial agents, are shown in Table 3(a) and (b). Both oils exhibited different levels of antimicrobial activity against the tested microorganisms. The $G$. rotundifolium oil showed moderate activity against Staphylococcus aureus and Staphylococcus epidermidis and weak activity against $E$. coli and had no activity at tested concentrations against Pseudomonas aeruginosa, Klebsiella pneumoniae and Enterobacter cloacae.

On the other hand, $H$. villosum oil showed very promising antimicrobial activity against all the tested microorganisms (bacteria and fungi) with minimum inhibitory concentrations ranging from 0.08 to $10.34 \mathrm{mg} / \mathrm{mL}$. Among the microorganisms, $S$. aureus was the most sensitive (MIC $0.08 \mathrm{mg} / \mathrm{mL}$ ) and E. coli was the least sensitive (MIC $10.34 \mathrm{mg} / \mathrm{mL}$ ).

\section{DISCUSSION}

The major compounds identified for the essential oil of $G$. rotundifolium were different from those identified previously for plants growing in Cameroon in which sesquiterpene hydrocarbons constituted $90.1 \%$ of the oil with germacrene $D$, $\beta$-caryophyllene and $\beta$-gurjunene being the major components [5]. The difference in the composition could be attributed to differences in the geographical location, climate, season and age at which the plants were collected.

It would be worth reporting that $H$. villosum oil was strongly active against $S$. mutans, $S$. viridis, Candida albicans, C. tropicalis and C. glabrata (with MIC's 0.14-0.94 mg/mL), which were resistant to oils from $G$. rotundifolium and other plants growing in Tanzania, as reported previously [10-12]. In addition, the essential from G. rotundifolium was devoid of antifungal activity against the tested Candida species unlike the essential oil growing in Cameroon which was previously reported to have shown significant antifungal activity against Fusarium moniliforme and Rhizopus stolonifera [15]. 
Table 1: Chemical composition of the essential oil of Geniosporum rotundifolium

\begin{tabular}{|c|c|c|c|c|c|}
\hline No. & Constituent & $\%$ & $\mathbf{K I}_{(\alpha)}$ & $\mathrm{KI}_{(\alpha 1)}$ & $\mathbf{K \mathbf { I } _ { ( \beta ) }}$ \\
\hline 1 & $\alpha$-Pinene & 2.49 & 936 & 935 & 939 \\
\hline 2 & Camphene & 1.10 & 951 & 949 & 951 \\
\hline 3 & $\beta$-Pinene & 1.82 & 978 & 976 & 979 \\
\hline 4 & 1-Octen-3-ol & 0.73 & 983 & 981 & 979 \\
\hline 5 & 3-Octanol & 0.65 & 988 & 995 & 991 \\
\hline 6 & $p$-Cymene & 1.48 & 1027 & 1025 & 1025 \\
\hline 7 & Limonene & 2.65 & 1031 & 1029 & 1029 \\
\hline 8 & Eucalyptol & 1.10 & 1033 & 1031 & 1031 \\
\hline 9 & Cis-ocimene & 0.49 & 1042 & 1040 & 1037 \\
\hline 10 & Trans- $\beta$-Ocimene & 0.30 & 1052 & & 1050 \\
\hline 11 & $\gamma$-Terpinene & 0.32 & 1061 & & 1060 \\
\hline 12 & cis-Sabinene hydrate & 0.61 & 1069 & 1068 & 1070 \\
\hline 13 & $\alpha$-Terpinolene & 0.28 & 1088 & & 1089 \\
\hline 14 & Linalool & 2.43 & 1102 & & 1097 \\
\hline 15 & $\alpha$-Thujone & 0.74 & 1104 & 1103 & 1102 \\
\hline 16 & $\alpha$-Camphonelal & 0.39 & 1127 & 1125 & 1126 \\
\hline 17 & Trans-pinocarveol & 1.17 & 1139 & 1138 & 1139 \\
\hline 18 & Camphor & 2.28 & 1144 & 1143 & 1146 \\
\hline 19 & $\varepsilon$-Myroxide & 1.14 & 1146 & 1145 & 1145 \\
\hline 20 & Borneol & 1.26 & 1166 & 1169 & 1165 \\
\hline 21 & Terpinen-4-ol & 2.85 & 1178 & 1177 & 1177 \\
\hline 22 & $\alpha$-Terpineol & 4.65 & 1191 & 1190 & 1189 \\
\hline 23 & Myrtenal & $\operatorname{tr}$ & 1193 & & 1196 \\
\hline 24 & Unknown & 2.10 & 1196 & 1194 & \\
\hline 25 & Verbenone & 0.40 & 1206 & 1206 & 1205 \\
\hline 26 & carveol & 0.72 & 1220 & 1219 & 1217 \\
\hline 27 & Carv & 0.42 & 1244 & 1244 & 1243 \\
\hline 28 & iglate & 0.56 & 1333 & 1331 & 1333 \\
\hline 29 & ebene & 0.60 & 1347 & 1347 & 1351 \\
\hline 30 & Eugenol & 2.09 & 1359 & 1358 & 1359 \\
\hline 31 & $\alpha-\mathrm{Cop}$ & 2.83 & 1372 & 1373 & 1377 \\
\hline 32 & $\beta$-Bourbonene & 2.91 & 1379 & 1381 & 1388 \\
\hline 33 & trans- $\beta$-Damascenone & 0.60 & 1382 & 1382 & 1385 \\
\hline 34 & $\beta$-Elemene & 1.66 & 1387 & 1387 & 1391 \\
\hline 35 & Methyl eugenol & 1.34 & 1406 & 1404 & 1404 \\
\hline 36 & $\beta$-Caryophyllene & 2.09 & 1411 & 1414 & 1419 \\
\hline 37 & $\beta$-Gurjunene & 0.91 & 1423 & 1425 & 1434 \\
\hline 38 & $\alpha$-Bergamotene & 0.77 & 1432 & 1432 & 1435 \\
\hline 39 & $\alpha$-Humulene & 0.52 & 1447 & 1449 & 1455 \\
\hline 40 & Alloaromadendrene & 1.15 & 1453 & 1456 & 1460 \\
\hline 41 & $\alpha$-Amorphene & 1.62 & 1472 & 1472 & 1485 \\
\hline 42 & Germacrene-d & 3.71 & 1475 & 1476 & 1485 \\
\hline 43 & Ar-curcumene & 0.31 & 1479 & & 1481 \\
\hline 44 & $\beta$-Ionone & 0.74 & 1482 & 1482 & 1489 \\
\hline 45 & $\begin{array}{l}\text { Epi- } \\
\text { bicyclosesquiphellandrene }\end{array}$ & 1.17 & 1488 & 1486 & 1494 \\
\hline 46 & $\alpha$-Muurolene & 0.75 & 1494 & 1490 & 1500 \\
\hline 47 & $\Gamma-\mathrm{Cad}$ & 0.74 & 1506 & 1509 & 1514 \\
\hline 48 & $\Delta-\mathrm{Ca}$ & 2.68 & 1519 & 1520 & 1523 \\
\hline 49 & corene & 0.54 & 1537 & 1539 & 1546 \\
\hline 50 & Cerolidol & 0.42 & 1564 & & 1563 \\
\hline 51 & Spathulenol & 12.46 & 1574 & 1576 & 1578 \\
\hline 52 & Caryophyllene os & 2.6 & 1575 & 1579 & 1583 \\
\hline 53 & Salvial-4(14)-en-1-one & 0.85 & 1585 & 1588 & 1595 \\
\hline 54 & Unknown & 1.58 & 1602 & 1604 & \\
\hline 55 & Unknown & 1.78 & 1648 & 1653 & \\
\hline 56 & $\alpha$-Cadinol & 1.69 & 1652 & 1655 & 1654 \\
\hline 57 & Cadalene & 0.78 & 1671 & 1676 & 1677 \\
\hline 58 & Unknown & 1.25 & 1686 & 1692 & \\
\hline \multirow[t]{2}{*}{59} & Unknown & 2.88 & & 2168 & \\
\hline & Total & 91.15 & & & \\
\hline
\end{tabular}


Table 2: Chemical composition of the essential oil of Haumaniastrum villosum

\begin{tabular}{|c|c|c|c|c|}
\hline No. & Constituent & $\%$ & $\mathrm{KI}_{(\boldsymbol{\alpha})}$ & $\mathbf{K I}_{(\beta)}$ \\
\hline 1 & $\alpha$-Pinene & 0.14 & 937 & 939 \\
\hline 2 & $\beta$-Pinene & 0.11 & 978 & 979 \\
\hline 3 & 1-Octen-3-ol & 0.33 & 983 & 979 \\
\hline 4 & p-Cymene & 0.14 & 1027 & 1025 \\
\hline 5 & Limonene & 0.27 & 1031 & 1029 \\
\hline 6 & Eucalyptol & 0.29 & 1033 & 1031 \\
\hline 7 & Trans-pinocarveol & 0.17 & 1141 & 1139 \\
\hline 8 & Camphor & 0.33 & 1145 & 1146 \\
\hline 9 & Menthone & 0.63 & 1156 & 1163 \\
\hline 10 & Isomenthone & 1.32 & 1166 & 1163 \\
\hline 11 & Neomenthol & 1.16 & 1166 & 1166 \\
\hline 12 & $\alpha$-Terpineol & 0.10 & 1192 & 1189 \\
\hline 13 & Linalool & 1.26 & 1101 & 1097 \\
\hline 14 & Pulegone & 0.55 & 1241 & 1237 \\
\hline 15 & Piperitone & 0.40 & 1256 & 1253 \\
\hline 16 & $\alpha$-Cubebene & 0.45 & 1350 & 1351 \\
\hline 17 & Cycloisosativene & 0.70 & 1366 & 1364 \\
\hline 18 & $\alpha$-Ylangene & 3.32 & 1371 & 1375 \\
\hline 19 & $\alpha$-Copaene & 1.35 & 1375 & 1377 \\
\hline 20 & $\beta$-Bourbonene & 5.70 & 1384 & 1388 \\
\hline 21 & $\beta$-Cubebene & 0.81 & 1389 & 1388 \\
\hline 22 & $\beta$-Elemene & 1.00 & 1391 & 1391 \\
\hline 23 & $\beta$-Caryophyllene & 5.39 & 1417 & 1419 \\
\hline 24 & $\alpha$ - Humulene & 5.63 & 1453 & 1455 \\
\hline 25 & Trans- $\beta$-Farnesene & 0.32 & 1457 & 1457 \\
\hline 26 & Alloaromadendrene & 0.17 & 1475 & 1485 \\
\hline 27 & $\alpha$-Amorphene & 1.34 & 1475 & \\
\hline 28 & Germacrene-d & 0.70 & 1479 & \\
\hline 29 & $\beta$-Selinene & 0.74 & 1484 & 1485 \\
\hline 30 & $\alpha$-Muurolene & 0.57 & 1497 & 1485 \\
\hline 31 & $\beta$-Bisabolene & 0.15 & 1508 & 1490 \\
\hline 32 & $y$-Cadinene & 3.61 & 1512 & 1500 \\
\hline 33 & Trans-calamenene & 0.97 & 1523 & 1506 \\
\hline 34 & $\delta$-Cadinene & 0.42 & 1530 & 1514 \\
\hline 35 & $\alpha$-Cadinene & 0.24 & 1537 & 1529 \\
\hline 36 & Elemol & 2.79 & 1551 & 1523 \\
\hline 37 & Caryophyllene oxide & 19.01 & 1583 & 1539 \\
\hline 38 & Salvial-4(14)-en-1-one & 1.24 & 1592 & 1550 \\
\hline 39 & Humuleneepoxide II & 11.95 & 1609 & 1583 \\
\hline 40 & Unknown & 3.28 & 1615 & 1595 \\
\hline 41 & Unknown & 2.60 & 1622 & 1608 \\
\hline 42 & $\beta$-Eudesmol & 1.00 & 1652 & 1651 \\
\hline \multirow[t]{2}{*}{43} & $\alpha$-Cadinol & 2.95 & 1656 & 1654 \\
\hline & Total & 85.60 & & \\
\hline
\end{tabular}


Table 3(a): Antimicrobial activity (MIC, $\mathrm{mg} / \mathrm{mL}$ ) of the essential oils and identified pure compounds

\begin{tabular}{|c|c|c|c|c|c|c|c|c|c|c|c|}
\hline $\begin{array}{l}\text { Essential } \\
\text { oil/compound }\end{array}$ & 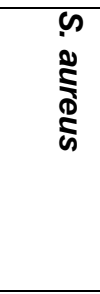 & $\begin{array}{l}\text { c) } \\
\frac{0}{2} \\
\frac{2}{2} \\
\frac{9}{2} \\
\frac{2}{3} \\
\frac{2}{4}\end{array}$ & 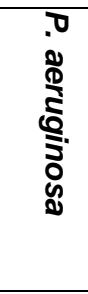 & 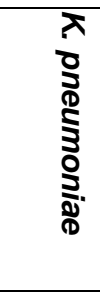 & 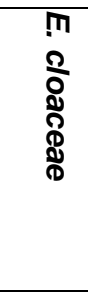 & 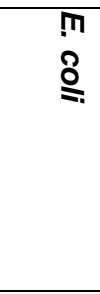 & 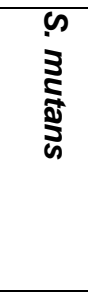 & 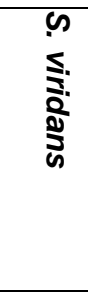 & 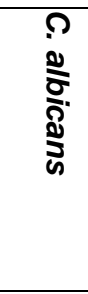 & 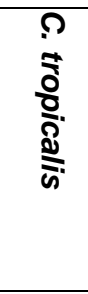 & 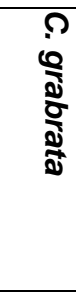 \\
\hline G. rotundifolium & 3.25 & 3.50 & $>20$ & $>20$ & $>20$ & 18.50 & - & - & - & - & - \\
\hline H. villosum & 0.08 & 0.95 & 1.25 & 1.37 & 2.50 & 10.34 & 0.14 & 0.39 & 0.94 & 0.74 & 0.82 \\
\hline 1,8-Cineole & 9.50 & 9.50 & 2.75 & 2.35 & 3.00 & 2.00 & - & - & - & - & - \\
\hline Limonene & $>20$ & $>20$ & $>25$ & $>25$ & $>25$ & $>20$ & - & - & - & - & - \\
\hline Linalool & 0.25 & 0.25 & $>20$ & $>20$ & 1.75 & 1.25 & 0.37 & 0.45 & - & - & - \\
\hline Camphor & 2.70 & 1.95 & 2.80 & 3.24 & 2.75 & 1.33 & - & - & 4.85 & 3.76 & 3.56 \\
\hline Pulegone & 1.20 & 0.95 & 1.45 & 1.76 & 1.37 & 1.45 & 1.75 & 1.26 & - & - & - \\
\hline Piperitone & 1.50 & 2.25 & 0.60 & 0.80 & 1.10 & 0.95 & - & - & - & - & - \\
\hline Bornyl acetate & 1.95 & 1.75 & 2.30 & 3.25 & 3.75 & 4.88 & - & - & - & - & - \\
\hline Borneol & 1.25 & 1.57 & 2.50 & 3.75 & 4.20 & 4.50 & - & - & - & - & - \\
\hline Spathulenol & 1.35 & 1.50 & $>20$ & $>20$ & $>20$ & 8.50 & - & - & - & - & - \\
\hline a-Pinene & 7.50 & 9.50 & 6.00 & 15.00 & 8.00 & 2.00 & - & - & 4.00 & 4.00 & 2.00 \\
\hline$\beta$-Pinene & 12.00 & 16.00 & $>20$ & $>20$ & $>20$ & 9.75 & - & - & - & - & 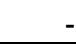 \\
\hline
\end{tabular}

Table 3(b): Antimicrobial activity (MIC, $\mathrm{mg} / \mathrm{mL}$ ) of the essential oils and identified pure compounds (contd)

\begin{tabular}{|c|c|c|c|c|c|c|c|c|c|c|c|}
\hline Essential oil/compound & $\begin{array}{l}\infty \\
\stackrel{D}{c} \\
\stackrel{c}{\bar{D}} \\
\frac{1}{\infty}\end{array}$ & 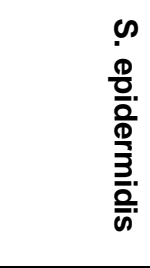 & 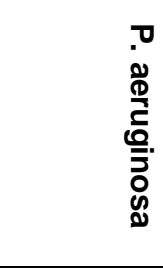 & 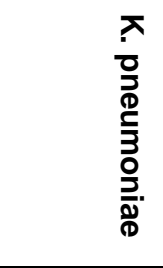 & 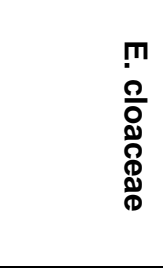 & 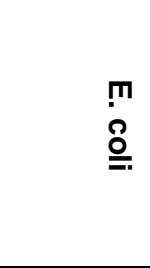 & 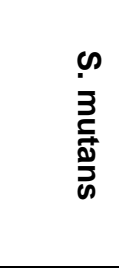 & 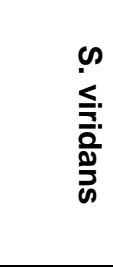 & 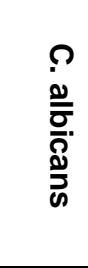 & $\begin{array}{l}\Omega \\
\overline{\overline{0}} \\
\frac{0}{\bar{D}} \\
\stackrel{0}{\bar{D}}\end{array}$ & 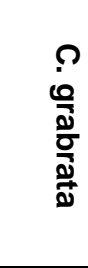 \\
\hline$\beta$ - Caryphylene & $>20$ & $>20$ & $>20$ & $>20$ & $>20$ & $>20$ & - & - & - & - & - \\
\hline$\beta$-Caryphyleneoxide & 0.073 & 0.90 & 0.87 & 1.23 & 2.43 & $>6.40$ & 0.25 & 0.75 & - & - & - \\
\hline Netilmicin & $4 \times 10^{-3}$ & $4 \times 10^{-3}$ & $8.8 \times 10_{-3}$ & $8 \times 10^{-3}$ & $8 \times 10^{-3}$ & $10-2$ & - & - & - & - & - \\
\hline Amoxycillin & $2 \times 10^{-3}$ & $2 \times 10^{-3}$ & $2.4 \times 10^{-3}$ & $2.2 \times 10^{-3}$ & $2.8 \times 10^{-3}$ & $2 \times 10^{-3}$ & - & - & - & - & - \\
\hline
\end{tabular}


The observed antimicrobial activity in the studied essential oils could be attributed to their major components. In the case of $G$. rotundifolium, the activity could be mainly, due to the oxygenated sesquiterpene spathulenol, which showed two to three times more activity than the oil, while the activity of $H$. villosum oil compared well with that of $\beta$-caryophyllene oxide. The antimicrobial activity of these oils could also be attributed to the major and minor constituents of the oils, constituents with the known antimicrobial activity such as spathulenol [11], linalool [13] and camphor [14], and their synergistic effects.

\section{CONCLUSION}

The composition and antimicrobial potential of two aromatic plants of Tanzania, Geniosporum rotundifolium and Haumaniastrum villosum have been determined for the first time. $H$. villosum shows good antimicrobial activity and hence should be further evaluated for possible use in preparations of pharmaceuticals for the management of disease conditions caused by these microorganisms, especially the oral and skin infections caused by Candida species.

\section{ACKNOWLEDGEMENT}

The authors are grateful for the funding provided by Muhimbili University of Health and Allied Sciences (MUHAS) through Sida Research Capacity Strengthening, which enabled us to accomplish this work. The assistance provided by technical staff at University of Athens, Athens, Greece and MUHAS for access to laboratory facilities, as well as the support received from late Rev Moses Mbila Mwakyendelwa during the collection of plant materials, are also highly appreciated.

\section{REFERENCES}

1. Baerts M, Lehmann J, Nales de Guérisseurs et plantes médicinales de la région des crêtesZaïre Nil au Burundi. Musée royal de l'Afrique centrale, Tervuren, Belgique. Ann. Sci. Econ. 1989; 1: 214.

2. Hutchinson J, Dalziel, JM. Flora of West Tropical Africa: Vol. 2, 2nd edn; Crown Agents for Overseas Governments \& Administration: London, 1963.
3. Geniosporum rotundifolium. Taxonomy. [EOL.org
[ET articles][cited $2010 \mathrm{Feb}$ 14]. Available from http://www.gwannon.com/species/Geniosporumrotundifolium.

4. Kamatenesi-Mugisha $M$, Oryem-Origa1 H, Odyek $O$, Makawiti DW. Medicinal plants used in the treatment of fungal and bacterial infections in and around Queen Elizabeth Biosphere Reserve, western Uganda. Afr .J. Ecol.2008; 46 (Suppl. 1: 90-97.

5. François $T$, Michel JDP, Vyry WNA, Fabrice FB, Lambert $S M$, Henri AZP, Chantal M. Composition and Antifungal Properties of Essential Oils from Five Plants Growing in the Mountainous Area of the West Cameroon, Journal of Essential Oil Bearing Plants, 2013; 16:5, 679-688,

6. Paton, A. A revision of Haumaniastrum (Labiatae), Kew Bulletin 1997; 52: 293-378.

7. Bin Mushambanyi TM. Local inhabitants' control strategies of crop pests in Eastern Democratic Republic of Congo, by exploiting the local plant diversity species. Delpinoan.s, 2002; 44: 65-74.

8. Massada Y. Analysis of Essential Oil by Gas Chromatography and Spectrometry; New York, John Wiley \& Sons, 1976.

9. Adams, R.P. Identification of Essential Oil Components by Gas Chromatography/Mass Spectrometry, 4th ed.; Carol Stream, IL, USA, Allured Publishing Co, 2007.

10. Ngassapa $O$, Runyoro DKB, Harvala E, Chinou IB. Composition and antimicrobial activity of the essential oils of two different populations of Lippia javanica growing in Tanzania. Flav. Frag. J.2003; 18: 221-224.

11. Bougatsos C, Ngassapa O,Runyoro DKB, Chinou IB. Chemical Composition and in vitro Antimicrobial Activity of the essential oils of two Helichrysum species from Tanzania. Zeitschr Naturforsch 2004; 59c: 368-372.

12. Vagionas K, Graikou K, Chinou IB, Runyoro D, Ngassapa $O$. Chemical analysis and antimicrobial activity of essential oils from the aromatic plants Artemisia afra Jacq. And Leonotis ocymifolia (Burm. F.) Iwarsson var raineriana (Vision1) Iwarsson growing in Tanzania. J. Essent. Oil Res. 2007; 19: 396-400.

13. Koutsoudaki C, Krsek, M, Rodger, A. Chemical composition and antibacterial activity of the essential oil and the gum of Pistacia lentiscus var. chia. J. Agric. Food Chem. 2005; 53: 7681-7685.

14. Kim KJ, Kim YH, Yu HH, Jeong SI, Cha JD, Kil BS, You YO. Antibacterial activity and chemical composition of essential oil of Chrysanthemum boreale. Planta Med. 2003; 69: 274-277. 